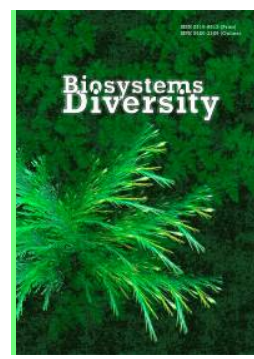

\title{
Impact of recreational transformation of soil physical properties on micromolluscs in an urban park
}

\author{
V. S. Budakova*, N. V. Yorkina*, P. M. Telyuk*, A. K. Umerova*, O. M. Kunakh**, O. V. Zhukov* \\ *Bogdan Khmelnitsky Melitopol State Pedagogical University, Melitopol, Ukraine \\ **Oles Honchar Dnipro National University, Dnipro, Ukraine
}

\section{Article info \\ Received 18.04.2021 \\ Received in revised form 10.05 .2021 \\ Accepted 12.05.2021}

Bogdan Khmelnitsk

Melitopol State

Pedagogical University,

Hetmanska st., 20

Melitopol, 72318, Ukraine

Tel.: +38-061-944-04-64

E-mail:

zhukov_dnipro@ukr.net

Oles Honchar Dnipro

National University

Gagarin av., 72,

Dnipro, 49000, Ukraine.

Tel.: +38-098-858-23-79.

E-mail:

kunah_olga@ukr.net
Budakova, V. S., Yorkina, N. V., Telyuk, P. M., Umerova, A. K., Kunakh, O. M., \& Zhukov, O. V. (2021). Impact of recreational transformation of soil physical properties on micromolluscs in an urban park. Biosystems Diversity, 29(2), 78-87. doi:10.15421/012111

The paper assesses the effect of transformation of soil physical properties on the abundance of micromolluscs in the conditions of an urban park. The studies were carried out in Novooleksandrivskiy Park (Melitopol, Ukraine). An experimental polygon was represented by 7 transects with 18 sampling points in each. The interval between the points in the transect, as well as the interval between transects, was 3 meters. The total area of the polygon was $1,134 \mathrm{~m}^{2}$. The tree species growing within the polygon were Quercus robur, Sophora japonica, and Acer campestre. Shrubs were represented by Ulmus laevis, Tilia cordata, Celtis occidentalis, and Morus nigra. The locations of the trees and shrubs were mapped. The crowns of tree and shrub plants formed a dense canopy and a shady light regime. The grass cover was practically absent. The soil mechanical resistance, soil aggregate-size distribution, electrical conductivity of soil, soil moisture and bulk density were measured. We recorded 618 individuals of Vallonia pulchella, 120 individuals of Cochlicopa lubrica, and 58 individuals of Acanthinula aculeata within the surveyed polygon. We extracted three principal components, which could explain $60.9 \%$ of the variation in the feature space of the soil properties. The principal component 1 explained $42.0 \%$ of the variation of the feature space and depended on the soil penetration resistance throughout the whole profile, aggregate composition, density, electric conductivity and moisture content of soil. This component reflected a tendency for soil penetration resistance and soil density to increase near recreational trails. The principal component 1 was used to indicate the gradient of recreational transformation of the soil. The principal component 2 was able to explain $10.6 \%$ of the variation in the feature space. It negatively correlated with the distance from the recreational trail, soil penetration resistance at the depth of $35 \mathrm{~cm}$ or more, soil electrical conductivity, and the proportion of aggregates greater than $3 \mathrm{~mm}$ in size. This component positively correlated with soil penetration resistance at $0-5 \mathrm{~cm}$ depth and the proportion of aggregates less than $0.5 \mathrm{~mm}$ in size. This component can be interpreted as a "halo" from the recreational trail, or a gradient of indirect soil transformations adjacent to the zone of intense recreational load. The principal component 3 was able to explain $8.3 \%$ of the variation in the feature space. It positively correlated with soil penetration resistance at the depth of 20-40 cm, the proportion of $0.5-7.0 \mathrm{~mm}$ aggregates, and soil moisture. It negatively correlated with the proportion of aggregates larger than $7 \mathrm{~mm}$ and smaller than $0.25 \mathrm{~mm}$. This component indicated a variation in soil properties that was induced by causes independent of recreational exposure. The extracted gradients of soil properties significantly influenced the abundance of micromollusc populations. The abundance of all species decreased after increase in recreational load. Micromollusc species responded to direct recreational exposure as plateau (C. lubrica) and asymmetric unimodal responses (V. pulchella and A. aculeata).

Keywords: species response; soil properties; ecological niche; transformation; hemeroby.

\section{Introduction}

Numerous studies have examined habitat preference and the effects of environmental factors on snails at the macroscale level (Karlin, 1961; Horsák \& Hájek, 2003; Horsák et al., 2007; Sulikowska-Drozd \& Horsák, 2007; Santos et al., 2012; Moreno-Rueda, 2014; Książkiewicz \& Gołdyn, 2015; Balashov et al., 2020). The moisture and available calcium content are the most important environmental factors controlling the species richness and composition of terrestrial mollusc communities (Čejka \& Hamerlík, 2009; Brygadyrenko, 2014). Species richness and abundance of terrestrial mollusc communities respond positively to available calcium or soil pH (Wäreborn, 1969; Horsák, 2006). The moisture and ecosystem productivity are essential ecological regimes structuring mollusc communities (Chiba, 2007). The distribution of molluscs was discussed in connection with litter moisture, shading, air humidity, ground water level (Kuczyńska \& Moorkens, 2010; Nunes \& Santos, 2012; Książkiewicz et al., 2013). At the landscape level, the calcium content in soil is the most important environmental factor determining the qualitative and quantitative characteristics of mollusc populations (Horsák \& Hájek, 2003; Sulikowska-Drozd \& Horsák, 2007). The amount of available calcium is a factor related to vegetation and affects snail distribution (Karlin, 1961). Also important gradients that affect clams are the thickness of leaf litter, the organic matter content of the topsoil, and the average annual temperature (Sulikowska-Drozd \& Horsák, 2007). Litter moisture levels appear to be particularly important for small litter-dwelling snails (Hylander et al., 2005; Kuczyńska \& Moorkens, 2010; Jankowiak \& Bernard, 2013; Książkiewicz et al., 2013). The ratio between litter cover and herbaceous vegetation has a significant effect on molluscs. The species richness of the mollusc communities strongly depends on the litter diversity, as individual mollusc species prefer the leaves of different tree species (Szybiak et al., 2009; Książkiewicz et al., 2013). A linear and bell-shaped relationship between soil moisture and the number of land snail species was documented (Hettenbergerová et al., 2013). The vegetation cover is an important factor that shapes the ecological conditions of molluscs (Stoll et al., 2012). The classification of sites based on mollusc data is applicable to vegetation data and vice versa. The vegetation composition is a more important factor in explaining mollusc species variation than soil water chemistry (Horsák \& Hájek, 2003).

Studies of the microspatial distribution of mollusc species within a site is of particular interest and practical importance (Nekola \& Smith, 1999; Juřičková et al., 2008; Cernohorsky et al., 2010; Kuczyńska \& Moorkens, 2010; Jankowiak \& Bernard, 2013; Myšák et al., 2013; Hettenbergerová et al., 2013; Książkiewicz et al., 2013; Schenková et al., 2014; Książkiewicz-Parulska \& Ablett, 2017; Kunakh et al., 2018). At the fine- 
scale level, the calcium content was a strong regulator of species composition, species richness, total community abundance, and individual species abundance (Juřičková et al., 2008). The selection of favourable microhabitats is one of the most effective mechanisms to avoid the extreme environmental conditions (Cowie, 2009; Machin, 2009; Scheffers et al., 2014). Land snail species tend to aggregate in the most favourable locations, rather than replacing one species with another (Boycott, 1934; Hylander et al., 2005; Horsák \& Cernohorsky, 2008; Książkiewicz-Parulska \& Pawlak, 2016). To explain such patterns, there were proposed the hypotheses of "nested habitats" and "nested habitat quality". The "nested habitats" hypothesis refers to situations where the nestedness of species depends on a nestedness of discrete habitats. The nested habitat quality hypothesis suggests that all species in a community increase in abundance along the same ecological gradient, but differ in specialization or tolerance. This hypothesis also assumes a weak inter- and intra-community competition (Hylander et al., 2005).

According to Shelford's law, a single factor has an effect when it is at the minimum or maximum of that species' tolerance zone (Shelford, 1911, 1931). In most cases, species do not respond to individual environmental factors, but to complex gradients of different environmental factors (Rydgren et al., 2003; de Fraga et al., 2018). Ecoclines, which can be represented by the DCA ordination axes, are considered as the markers of complex ecological gradients (Rydgren et al., 2003). To quantify complex environmental factors, indirect measurements or phytoindication methods are often used. Soil electrical conductivity is a reliable proxy measure of soil mineral richness (Horsák, 2006). Elevation was used as a surrogate for climate (Horáčková et al., 2014). The Ellenberg indicator values (Ellenberg et al., 1992) obtained from vegetation samples were used as a proxy for the soil moisture (Cejka et al., 2007; Čejka \& Hamerlík, 2009), and also for the light, soil moisture, soil reaction, and content of soil nutrients (Horáčková et al., 2014). Eutrophication was assessed using ecological indicator values of vascular plants (Zarzycki et al., 2002) for assessment of the microspatial distribution of molluscs (Książkiewicz-Parulska \& Ablett, 2017). Didukh phytoindication scales (Didukh, 2011) were used for the analysis of the spatial distribution of the ecological niche of the land snail Brephulopsis cylindrica in technosols (Zhukov et al., 2019).

Ecological gradients, which play an important role in the organization of natural ecosystems, are being significantly altered by urbanization (Brygadyrenko, 2015, 2016a, 2016b; Putchkov et al., 2019). This trend is reflected in the concept of homogenization across urban areas (Groffman et al., 2014). The proliferation of non-native snail species in urban environments can lead to biotic homogenization (Horsák et al., 2013). In the urban gradient of habitat degradation, there is a gradual decrease in the species richness of snail communities, especially regarding rare and anthropophobic species. The natural habitats are of particular importance for the maintenance of snail diversity in the urban environment (Horsák et al., 2009). In urban environments, habitat type has a strong influence on the diversity of terrestrial mollusc communities (Lososová et al., 2011). The coherence between environmental factors, which in natural conditions forms the specificity of the action of complex environmental gradients, is transformed by homogenization in the urban environment. Artificial urban soils, which contain large amounts of Ca minerals, have a high potential for $\mathrm{C}$ accumulation followed by sequestration of atmospheric $\mathrm{C}$ in the soil matrix in the form of calcium carbonate (Seifritz, 1990; Renforth et al., 2009; Jorat et al., 2020). Urbanization leads to alkalinization of the soil due to input of some alkaline ions, such as calcium ions $\left(\mathrm{Ca}^{2+}\right)$ or sodium ions (Na ${ }^{+}$) (Lovett et al., 2000; Pouyat et al., 2008). Urbanization leads to an increase in $\mathrm{pH}$, stock of carbonates and organic matter in soils (Asabere et al., 2018). Thus, urbanization affects environmental factors that are essential for terrestrial molluscs. However, if in natural conditions, soil electrical conductivity can be a proxy for edaphotope trophicity (Zhukov et al., 2016), then in an urban environment it is a marker of anthropogenic soil salinization as a result of applying antifreeze to roads (Smagin et al., 2006; Yurkova et al., 2009; Korchagina et al., 2014; Vasenev et al., 2017). Phytoindication scales of different authors were developed for the natural ecosystems. The possibility of their use for indication of natural gradients in the urban environment is not fully justified (Goncharenko \& Yatsenko, 2020). Hemeroby gradient occurs in the urban environment as a result of smoothing of natural gradients. It should be noted the difficulty of indica- ting hemerobia by traditional methods (Yorkina, 2016; Yorkina et al., 2019). Hemeroby is a degree of deviation of ecological conditions from the natural state (Hill et al., 2002). This deviation can result from the various anthropogenic influences, including recreation (Ihtimanski et al., 2020). Organisms with low dispersal capacity, such as snails, are very susceptible to anthropogenic activities. Micromolluscs $(<5 \mathrm{~mm}$ in diameter) are often more vulnerable to disturbance because of their very limited mobility and dispersal, and their high dependence on microenvironmental conditions (Baur \& Baur, 1988). Therefore, land snails are a good indicator for assessing the impact of urbanization (Ström et al., 2009). Terrestrial gastropods, especially snails, can be used as the potential bioindicator organisms for assessing the environmental quality and thus for predicting the potential hazards to human health (El-Gendy et al., 2021). Anthropogenic disturbances play a crucial role in shaping the species diversity and community structure of terrestrial snails (Douglas et al., 2013).

Urbanization has many forms and recreational load is an important aspect of anthropogenic influence in the urban environment. A change in the physical properties of soil is an important result of recreational load. However, the effect of soil physical properties on micromolluscs under conditions of urbanization has hardly been studied. Therefore, the objective of our article was assessing the effect of transformation of soil physical properties on the abundance of micromolluscs in the conditions of an urban park.

\section{Materials and methods}

An experimental polygon was located in Novooleksandrivskiy Park (Melitopol, Ukraine) and represented 7 transects with 18 test points in each (Fig. 1). The interval between points in the transect, as well as the interval between transects, was 3 meters. The total area of the polygon was $1,134 \mathrm{~m}^{2}$. The composition of tree species growing in the polygon included Quercus robur (1 ind., trunk diameter $103 \mathrm{~cm}$ ), Sophora japonica (11 ind., trunk diameter $39.2 \pm 6.3 \mathrm{~cm}$ ), and Acer campestre ( 2 ind., trunk diameter $32.5 \pm 3.5 \mathrm{~cm}$ ). Shrubs were represented by the Ulmus laevis (1 ind., trunk diameter $14 \mathrm{~cm})$, Tilia cordata (3 ind., trunk diameter $13.0 \pm$ $2.1 \mathrm{~cm})$, Celtis occidentalis (13 ind., trunk diameter $10.2 \pm 0.7 \mathrm{~cm})$, and Morus nigra (1 ind., trunk diameter $7.0 \mathrm{~cm}$ ). The crowns of tree and shrub plants formed a dense canopy and a shady light regime. The grass cover was practically absent. The litter was fragmentary and did not form a continuous cover, no more than $1 \mathrm{~cm}$ thick. There were 4 recreational trails with a total length of $56.8 \mathrm{~m}$ within the polygon. The width of the trails, marked by a zone of highly compacted soil surface, was approximately 1 meter. The surface covered by the recreational trails was $5.2 \%$ of the polygon area. The distance of the test point from the nearest tree and the nearest distance of the test point from the recreational trail were used as specific predictors.

Sampling was conducted in October 2020. At each sampling point, a soil sample of cylindrical shape (diameter $-9 \mathrm{~cm}$, height $-8 \mathrm{~cm}$, volume $\approx 500 \mathrm{~cm}^{3}$ ) was taken from the surface to a depth of $8 \mathrm{~cm}$. From this sample, 10 soil sub-samples weighing 10 grams were taken. Each sample was examined with a dissecting needle to collect micromolluscs (Yorkina et al., 2018).

The soil mechanical resistance was measured in the field using the Eijkelkamp manual penetrometer, to a depth of $50 \mathrm{~cm}$ at $5 \mathrm{~cm}$ intervals. The average error of the measurement results of the device was $\pm 8 \%$. Measurements were made using a cone with a cross section of $1 \mathrm{~cm}^{2}$. At each measurement point, the soil mechanical resistance was measured in only one replication. Soil aggregate-size distribution was determined in accordance with the Soil Sampling and Methods of Analysis Recommendations (Kroetsch \& Wang, 2008). To measure the electrical conductivity of soil in situ, we used an HI 76305 sensor (Hanna Instruments, Woodsocket, R. I.), working in conjunction with a portable instrument HI 993310. The tester estimates the total electrical conductivity of the soil, i.e. combined conductivity of soil air, water and particles (Yorkina et al., 2018). Soil moisture was measured in the field conditions using a dielectric digital moisture meter MG-44 (vlagomer.com.ua). The core method was used for measurement of the soil bulk density (Al-Shammary et al., 2018). The descriptive statistics were calculated using the program Statistica (Statsoft). The Kaiser-Meyer-Olkin index (KMO) was applied to 
assess the adequacy of the collected data for the application of principal component analysis (Kaiser, 1970, 1974; Kaiser \& Rice, 1974). The KMO calculation was performed in the library REdaS (Maier, 2015). The principal component analysis was performed using the princomp function. The optimal number of principal components was estimated using the Horn's parallel analysis (Horn, 1965), performed in the library paran (Dinno, 2018).

The principal component scores were used as integral markers of the environment properties gradients. Huisman-Olff-Fresco (HOF) (Huisman et al., 1993) models were used to explain the responses of species to environmental gradients. Huisman-Olff-Fresco (HOF) models allow achievement of statistical correctness, flexibility and possibility of ecological interpretation for modeling the responses of species to environmental gradients (Michaelis \& Diekmann, 2017). They were first developed by Huisman et al. (1993) as a set of the five hierarchical models with an increasing complexity. The following types of models were identified: no response (I), increasing or decreasing response without (II) or with (III) a plateau, and asymmetric (IV) and symmetric (IV) unimodal responses. This list of models was extended to include seven ecological models (Jansen \& Oksanen, 2013). In addition to the five model types mentioned above, bimodal asymmetric (VI) and symmetric (VII) response forms were included to deal with species that are constrained to the extreme gradient values due to competition. The parameters of the ecological niche of species can be calculated using the models and be used for further analysis (Michaelis \& Diekmann, 2017). To improve simulation results, model selection stability was tested using bootstrapping (100 samples, default package setting) to ensure model robustness, and using Akaike's information criterion corrected for small data sets (AICc, default setting) (Burnham \& Anderson, 2002). In cases where the two procedures differed in choosing the best type of model, the bootstrapping model was preferred (Michaelis \& Diekmann, 2017).

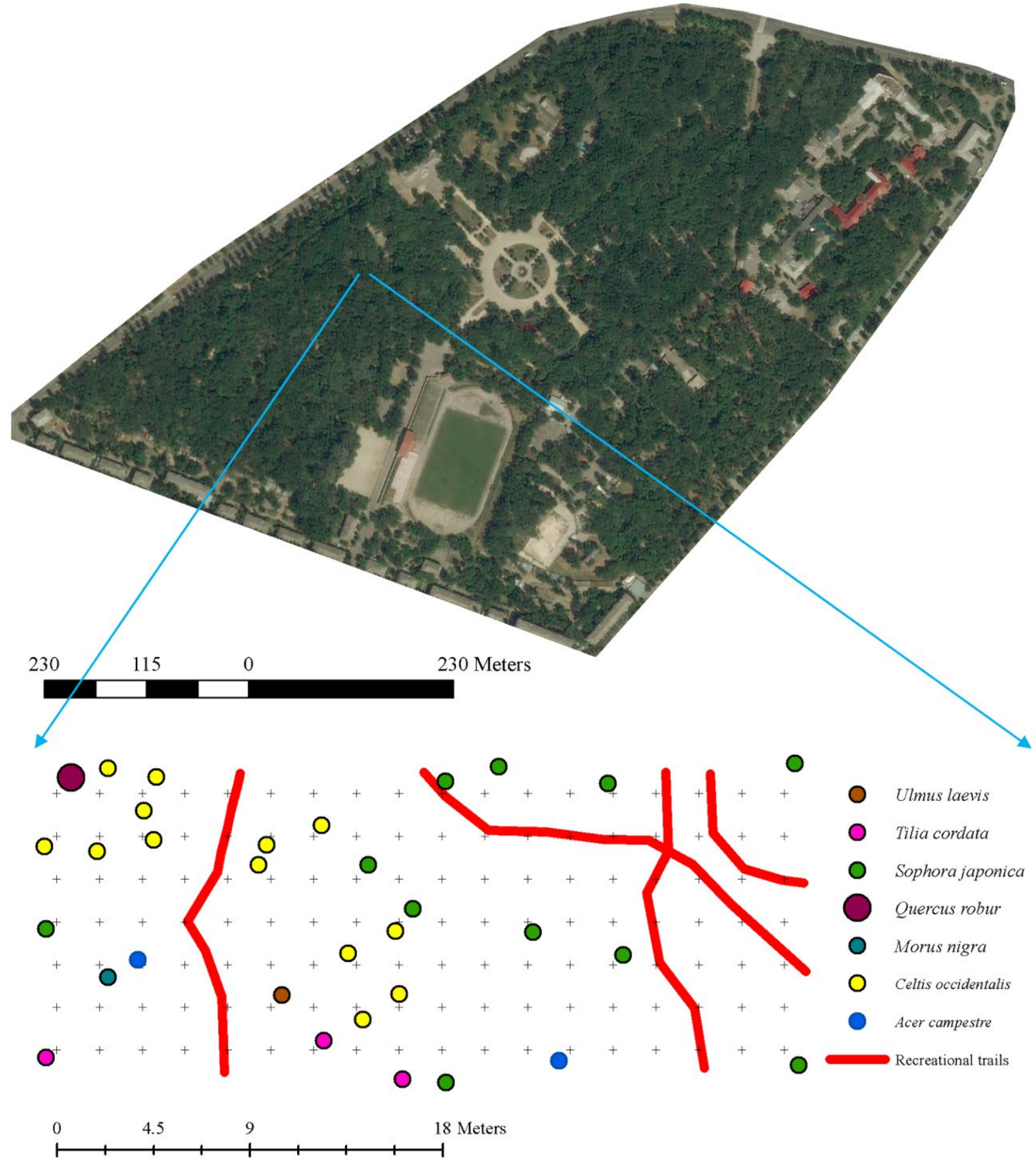

Fig. 1. Novooleksandrivsky Park (Melitopol) and experimental polygon: crosses show sampling points; circles show location of the trees and bushes within the polygon; $\mathrm{x}$-axis and $\mathrm{y}$-axis are the local coordinates of the polygon 
The response of species to an environmental gradient (shape of the response curve) is represented by the seven different typical models within the HOF approach. The Index of Qualitative Variation (IQV) was calculated as an evaluation of the stability of the model form. This index takes a value of zero if all repeated runs result in the same model shape, while it takes a value of one if all model types are chosen equally often (Mueller \& Schuessler, 1962). The index was calculated as:

$$
I Q V=\frac{1-\sum_{i=n} p_{i}^{2}}{\frac{1}{n} \times(n-1)},
$$

where $n$ is the number of model types, $p$ is the proportion for each models (Michaelis \& Diekmann, 2017).

The following parameters of the ecological niche were calculated based on response models: species optimum, maximum slope, inflection, central borders and outer borders. The species optimum describes the highest probability of occurrence of the species along the environment gradient. The maximum slope corresponds to the maximum value of the first derivative of the species response curve. The outer and central borders are given by the distance from the optimum that is needed for the response curve to drop a certain amount, i.e. these parameters represent the rate of decrease in the response in both directions from the optimum independent of each other. The central borders are calculated as the gradient values, where the response reaches "exp $(-1 / 2)$ " of the top. The outer borders of the species niche are calculated as the gradient values, where the response reaches $\exp (-2)$ of the top (Heegaard, 2002). The Huisman-Olff-Fresco models were computed using the statistical program R (v. 3.6.3; R Developmental Core Team) (R Core Team, 2020), with the package "eHOF" (version 1.9) (Jansen \& Oksanen, 2013).

\section{Results}

The records revealed 618 individuals of Vallonia pulchella (Müller, 1774), 120 individuals of Cochlicopa lubrica (Müller, 1774), and 58 individuals of Acanthimula aculeata (Müller, 1774) (Table 1). The level of variation in abundance of $V$. pulchella and Cochlicopa lubrica was not statistically significantly different $(\mathrm{F}=1.16, \mathrm{P}=0.42)$. The level of variation in A. aculeata abundance was higher compared with the other two.

The soil penetration resistance increased with depth up to $25-30 \mathrm{~cm}$, after which this index did not change significantly with depth (Table 2). The coefficient of variation of soil penetration resistance decreased with depth down to the $35-40 \mathrm{~cm}$ layer, after which this index practically did not change with depth. The skewness of the distribution of soil penetration resistance changed from positive to negative with increasing depth of the soil layer. The microaggregates (sized less than $0.25 \mathrm{~mm}$ ) dominated among the aggregate fractions. A relatively high proportion of macroaggregates (aggregates larger than $10 \mathrm{~mm}$ ) should also be noted.

Table 1

Descriptive statistics of the micromollusc populations

\begin{tabular}{|c|c|c|c|c|c|c|c|}
\hline \multirow{3}{*}{ Species } & \multicolumn{4}{|c|}{ Abundance, individuals } & \multirow{3}{*}{$\begin{array}{c}\mathrm{CV}, \\
\%\end{array}$} & \multirow{3}{*}{$\begin{array}{c}\text { Skewness } \\
\pm \mathrm{SE}\end{array}$} & \multirow{3}{*}{$\begin{array}{c}\text { Kurtosis } \\
\pm \mathrm{SE}\end{array}$} \\
\hline & \multirow[b]{2}{*}{ sum } & \multicolumn{3}{|c|}{ Per 100 gr of soil sample } & & & \\
\hline & & $\begin{array}{l}\text { mean } \\
\pm \mathrm{SE}\end{array}$ & $\begin{array}{l}\text { mini- } \\
\text { mum }\end{array}$ & $\begin{array}{l}\text { maxi- } \\
\text { mum }\end{array}$ & & & \\
\hline $\begin{array}{l}\text { Vallonia } \\
\text { pulchella }\end{array}$ & 618 & $\begin{array}{c}4.90 \\
\pm 0.60\end{array}$ & 0 & 24 & 136.9 & $\begin{array}{c}1.53 \\
\pm 0.22\end{array}$ & $\begin{array}{c}1.27 \\
\pm 0.43\end{array}$ \\
\hline $\begin{array}{l}\text { Cochlicopa } \\
\text { lubrica }\end{array}$ & 120 & $\begin{array}{c}0.95 \\
\pm 0.12\end{array}$ & 0 & 7 & 144.8 & $\begin{array}{c}1.96 \\
\pm 0.22\end{array}$ & $\begin{array}{c}4.18 \\
\pm 0.43\end{array}$ \\
\hline $\begin{array}{l}\text { Acanthinula } \\
\text { aculeata }\end{array}$ & 58 & $\begin{array}{c}0.46 \\
\pm 0.08 \\
\end{array}$ & 0 & 3 & 187.7 & $\begin{array}{c}1.75 \\
\pm 0.22 \\
\end{array}$ & $\begin{array}{c}1.86 \\
\pm 0.43\end{array}$ \\
\hline
\end{tabular}

The coefficient of variation of the proportions of aggregate fractions was in the range of $13.7-37.3 \%$. The soil electrical conductivity ranged 0.03 to $0.11 \mathrm{dSm} / \mathrm{m}$, which was much less than the critical level that was considered to be $2.0 \mathrm{dSm} / \mathrm{m}$ for the urban soils. The soil moisture content varied in the range of $6.1-11.4 \%$. The range of soil density variation was $0.96-1.35 \mathrm{~g} / \mathrm{cm}^{3}$. The distance of sample points from trees was in the range of $0.32-8.59 \mathrm{~m}$, and from recreational trails $-0.00-10.18 \mathrm{~m}$. It should be noted that there was a statistically significant negative correlation between these parameters $(\mathrm{r}=0.41, \mathrm{P}<0.001)$. Three principal components were extracted as a result of principal component analysis of the soil properties, which could explain $60.9 \%$ of the variation in the feature space (Table 3 ). The principal component 1 explained $42.0 \%$ of the variation of the feature space and depended on the soil penetration resistance over the whole profile, aggregate composition, density, electric conductivity and moisture content in soil. This component reflected a tendency for soil penetration resistance and soil density to increase as recreational trails were approached. This trend was also associated with a decrease in the soil moisture and electrical conductivity, as well as an increase in the proportion of aggregates larger than $10 \mathrm{~mm}$ and smaller than $0.5 \mathrm{~mm}$. Obviously, the principal component 1 indicates the gradient of recreational transformation of the soil.

Table 2

Descriptive statistics of the soil properties and distances from the trees and from the recreational trails

\begin{tabular}{|c|c|c|c|c|c|c|}
\hline Variables & Mean \pm SE & Minimum & Maximum & $\mathrm{CV}, \%$ & Skewness \pm SE & Kurtosis $\pm \mathrm{SE}$ \\
\hline \multicolumn{7}{|c|}{ Soil penetration resistance at a depth of, $\mathrm{cm}$ in $\mathrm{MPa}$} \\
\hline $0-5$ & $2.97 \pm 0.09$ & 1.10 & 5.80 & 33.71 & $0.77 \pm 0.22$ & $0.02 \pm 0.43$ \\
\hline $5-10$ & $4.72 \pm 0.12$ & 2.60 & 8.00 & 28.65 & $0.62 \pm 0.22$ & $-0.63 \pm 0.43$ \\
\hline $10-15$ & $6.10 \pm 0.14$ & 3.40 & 9.67 & 25.13 & $0.38 \pm 0.22$ & $-0.68 \pm 0.43$ \\
\hline $15-20$ & $6.93 \pm 0.14$ & 4.00 & 9.86 & 22.24 & $0.13 \pm 0.22$ & $-0.94 \pm 0.43$ \\
\hline $20-25$ & $7.67 \pm 0.12$ & 4.60 & 9.87 & 18.19 & $-0.44 \pm 0.22$ & $-0.72 \pm 0.43$ \\
\hline $25-30$ & $8.19 \pm 0.11$ & 5.00 & 10.00 & 14.62 & $-0.60 \pm 0.22$ & $-0.34 \pm 0.43$ \\
\hline $30-35$ & $8.35 \pm 0.08$ & 5.80 & 9.90 & 11.09 & $-0.62 \pm 0.22$ & $0.03 \pm 0.43$ \\
\hline $35-40$ & $8.66 \pm 0.08$ & 6.00 & 10.60 & 10.87 & $-0.62 \pm 0.22$ & $0.34 \pm 0.43$ \\
\hline $40-45$ & $8.48 \pm 0.09$ & 5.94 & 10.04 & 11.67 & $-0.76 \pm 0.22$ & $0.01 \pm 0.43$ \\
\hline $45-50$ & $8.17 \pm 0.09$ & 5.60 & 9.86 & 11.71 & $-0.76 \pm 0.22$ & $0.05 \pm 0.43$ \\
\hline \multicolumn{7}{|c|}{ Aggregate fraction, in \% } \\
\hline$>10 \mathrm{~mm}$ & $11.25 \pm 0.37$ & 2.62 & 20.75 & 37.27 & $0.08 \pm 0.22$ & $-0.49 \pm 0.43$ \\
\hline $7-10 \mathrm{~mm}$ & $7.23 \pm 0.09$ & 5.40 & 9.55 & 13.67 & $0.18 \pm 0.22$ & $-0.66 \pm 0.43$ \\
\hline $5-7 \mathrm{~mm}$ & $8.08 \pm 0.12$ & 5.36 & 11.10 & 16.59 & $0.12 \pm 0.22$ & $-0.73 \pm 0.43$ \\
\hline $3-5 \mathrm{~mm}$ & $10.68 \pm 0.17$ & 6.17 & 14.37 & 18.35 & $-0.26 \pm 0.22$ & $-0.75 \pm 0.43$ \\
\hline $2-3 \mathrm{~mm}$ & $9.58 \pm 0.18$ & 4.26 & 14.33 & 21.06 & $-0.08 \pm 0.22$ & $-0.16 \pm 0.43$ \\
\hline $1-2 \mathrm{~mm}$ & $13.18 \pm 0.25$ & 6.07 & 20.57 & 21.22 & $0.25 \pm 0.22$ & $0.18 \pm 0.43$ \\
\hline $0.5-1 \mathrm{~mm}$ & $2.45 \pm 0.04$ & 1.57 & 3.45 & 17.58 & $0.01 \pm 0.22$ & $-0.45 \pm 0.43$ \\
\hline $0.25-0.5 \mathrm{~mm}$ & $12.59 \pm 0.26$ & 7.66 & 18.83 & 23.04 & $0.25 \pm 0.22$ & $-0.87 \pm 0.43$ \\
\hline$<0.25 \mathrm{~mm}$ & $25.00 \pm 0.40$ & 15.38 & 37.54 & 17.89 & $0.42 \pm 0.22$ & $0.30 \pm 0.43$ \\
\hline \multicolumn{7}{|c|}{ Other soil properties } \\
\hline Electrical conductivity, $\mathrm{dSm} / \mathrm{m}$ & $0.07 \pm 0.00$ & 0.03 & 0.11 & 17.87 & $0.23 \pm 0.22$ & $0.68 \pm 0.43$ \\
\hline Soil moisture, $\%$ & $9.31 \pm 0.10$ & 6.10 & 11.41 & 12.22 & $-0.78 \pm 0.22$ & $0.14 \pm 0.43$ \\
\hline Soil bulk density, $\mathrm{g} / \mathrm{cm}^{3}$ & $1.10 \pm 0.01$ & 0.96 & 1.35 & 8.56 & $0.88 \pm 0.22$ & $0.04 \pm 0.43$ \\
\hline \multicolumn{7}{|c|}{ Distance, $m$} \\
\hline From the trees & $2.54 \pm 0.15$ & 0.32 & 8.59 & 67.05 & $1.38 \pm 0.22$ & $2.28 \pm 0.43$ \\
\hline From the recreational trails & $3.25 \pm 0.22$ & 0.00 & 10.18 & 77.35 & $0.61 \pm 0.22$ & $-0.57 \pm 0.43$ \\
\hline
\end{tabular}


Table 3

Results of Horn's Parallel Analysis for component retention after 5,000 iterations (KMO-Criterion 0.81 - according to the rule of thumb suggested in Kaiser (1974) and Kaiser \& Rice (1974), the value can be recognized as meritorious

\begin{tabular}{cccccc}
\hline Component & Eigenvalue & Eigenvalue & Bias & $\begin{array}{c}\text { Variation } \\
\text { explained, \% }\end{array}$ & $\begin{array}{c}\text { Standard } \\
\text { deviation }\end{array}$ \\
\hline 1 & 9.19 & 10.08 & 0.90 & 42.02 & 3.16 \\
2 & 1.80 & 2.53 & 0.74 & 10.56 & 1.59 \\
3 & 1.37 & 1.99 & 0.62 & 8.31 & 1.41 \\
\hline
\end{tabular}

The principal component 2 was able to explain $10.6 \%$ of the variation in the feature space. It negatively correlated with distance from the recreational trail, soil penetration resistance at the depth of $35 \mathrm{~cm}$ or more, soil electrical conductivity, and the proportion of aggregates greater than $3 \mathrm{~mm}$ in size. This component positively correlated with soil penetration resistance at $0-5 \mathrm{~cm}$ depth and the proportion of aggregates less than $0.5 \mathrm{~mm}$ in size. This component can be interpreted as a "halo" from the recreational trail, or a gradient of indirect soil transformations adjacent to the zone of intense recreational load.

The principal component 3 was able to explain $8.3 \%$ of the variation in the feature space. It positively correlated with soil penetration resistance at the depth of $20-40 \mathrm{~cm}$, the proportion of aggregates $0.5-7 \mathrm{~mm}$ in size, and soil moisture. It negatively correlated with the proportion of aggregates larger than $7 \mathrm{~mm}$ and smaller than $0.25 \mathrm{~mm}$. This component indicated a variation in soil properties that was induced by causes independent of recreational exposure.

The extracted gradients of soil properties significantly influenced the abundance of micromollusc populations (Table 2). The abundance of all species decreased with increasing recreational load, which was marked by the principal component 1 . The response of micromollusc species to direct recreational exposure was of plateau $(C$. lubrica) and asymmetric unimodal responses ( $V$. pulchella and $A$. aculeate, Fig. 3). The optimum zone of $V$. pulchella was in the range of low recreational load. The optimum zone of A. aculeata was in the range of moderate recreational load. The micromollusc $C$. lubrica was sensitive only to high levels of recreational load, and the species was indifferent to moderate or low recreational load.

The micromollusc $V$. pulchella was sensitive to indirect recreational exposure as marked by the principal component 2 . Other species were indifferent to the action of this gradient.

Micromolluscs $V$. pulchella and C. lubrica were sensitive to the natural variability of soil properties, which were marked by the principal component 3. The increase in the proportions of $0.5-7 \mathrm{~mm}$ fractions had a positive effect on the abundance of $V$. pulchella molluscs. There was a proportion of these aggregate fractions at which the abundance of $C$. lubrica could be greatest. The response of $A$. aculeata to natural variability in soil properties was not explicit.

Species response patterns can be estimated not only for integral variables, but also for traits that characterize individual soil properties or other ecological indicators (Table 1). Thus, the data obtained indicate that close proximity to trees creates favourable living conditions for all molluscan species. On the other hand, the distance less than 1-2 meters from the recreational trails is an unfavourable zone for the existence of micromolluscs. The micromollusc $V$. pulchella was sensitive to all soil properties. Also, an increase in the abundance of this species was observed in conditions of high proportion of aggregates $0.5-7 \mathrm{~mm}$ in size, while other species were less sensitive to soil aggregate structure.

\section{Discussion}

Park plantings in the city are represented by a wide variety of the plant species, among which cultivated or invasive species play an important role. The phytoindication role of these plant species is highly questionable, so it is difficult to rely on artificial plant communities for ecological assessments. In this regard, the soil properties are extremely informative for assessing the degree of recreational impact on ecosystems. The role of the scale at which recreation occurs should also be considered (Graham \& Eigenbrod, 2019; Zhukov et al., 2019). The recreational trails are an important aspect of the impact on the soil (Ballantyne \& Pickering, 2015;
Huang et al., 2015; Tomczyk \& Ewertowski, 2016). Such impact is associated with compaction of the soil (Azlin \& Philip, 2004; Ballantyne \& Pickering, 2015), an increase in soil penetration resistance (Landsberg et al., 2003; Campbell et al., 2013), changes in the soil aggregate structure (Bird et al., 2007; Fattet et al., 2011). As our results show, the mentioned soil properties are extremely important for determining the living conditions of micromolluscs.

The soil sampling was proposed to record soil micromolluscs, followed by its analysis under a microscope in the laboratory. This method originated in paleozoology (Evans, 1972). The abundance of micromolluscs in the park plantation is quite high. On average of 4.9 individuals of Vallonia pulchella, 0.95 individuals of Cochlicopa lubrica, and 0.46 individuals of Acanthinula aculeata were found per 100 grams of soil. This is equivalent to 4,312 individuals $/ \mathrm{m}^{2}$ of Vallonia pulchella, 836 individuals $/ \mathrm{m}^{2}$ of Cochlicopa lubrica, and 405 individuals $/ \mathrm{m}^{2}$ of Acanthinula aculeata. Using this approach, Davies et al. (1996) found that V. pulchella abundance ranged 0.440 .4 individuals per $100 \mathrm{~g}$ of soil sample on chalk soils in Great Britain. For Jurassic limestone in central Krakow, the abundance of this species was 1-22 individuals per $100 \mathrm{~g}$ of soil sample (GołasSiarzewska, 2013). In technozems, where the counting was carried out by a similar methodology, the abundance of $V$. pulchella was 1.8 individuals per 100 grams of soil, and representatives of C. lubrica and A. aculeata were not found (Kunakh et al., 2018).

Three gradients were identified in the variation of soil properties, of which only the principal component 3 is a variability that is independent of recreational exposure. The principal components 1 and 2 are a consequence of recreational exposure and together they explain $56.6 \%$ of the variation in the feature space, with recreational trails covering about $5.2 \%$ of the polygon area. This ratio indicates that the influence of recreational trails extends well outside their apparent boundaries. Principal component 1 is a marker of direct recreational impact, indicating increase in penetration resistance throughout the soil profile as recreational load increases. The correlation of principal component 1 and penetration resistance values decreases with increase in the soil layer depth, indicating that recreational soil compaction decays with depth.

\section{Table 4}

Principal components loadings of the manifest variables (statistically significant loadings at $\mathrm{P}<0.05$ are presented)

\begin{tabular}{|c|c|c|c|}
\hline Variables & $\mathrm{PC} 1$ & $\mathrm{PC} 2$ & PC3 \\
\hline \multicolumn{4}{|c|}{ Soil penetration resistance at a depth of, $\mathrm{cm}$} \\
\hline $0-5$ & 0.27 & 0.14 & - \\
\hline $5-10$ & 0.28 & - & - \\
\hline $10-15$ & 0.27 & - & - \\
\hline $15-20$ & 0.26 & - & - \\
\hline $20-25$ & 0.22 & - & 0.24 \\
\hline $25-30$ & 0.21 & - & 0.25 \\
\hline $30-35$ & 0.21 & -0.22 & 0.21 \\
\hline $35-40$ & 0.20 & -0.28 & 0.23 \\
\hline $40-45$ & 0.14 & -0.44 & - \\
\hline $45-50$ & 0.09 & -0.49 & - \\
\hline \multicolumn{4}{|c|}{ Aggregate fraction } \\
\hline$>10 \mathrm{~mm}$ & 0.17 & -0.25 & -0.41 \\
\hline $7-10 \mathrm{~mm}$ & 0.06 & -0.33 & -0.36 \\
\hline $5-7 \mathrm{~mm}$ & -0.22 & -0.13 & 0.24 \\
\hline $3-5 \mathrm{~mm}$ & -0.25 & -0.15 & 0.28 \\
\hline $2-3 \mathrm{~mm}$ & -0.25 & - & 0.25 \\
\hline $1-2 \mathrm{~mm}$ & -0.08 & - & 0.33 \\
\hline $0.5-1 \mathrm{~mm}$ & -0.16 & - & 0.23 \\
\hline $0.25-0.5 \mathrm{~mm}$ & 0.17 & 0.23 & - \\
\hline$<0.25 \mathrm{~mm}$ & 0.08 & 0.27 & -0.13 \\
\hline \multicolumn{4}{|c|}{ Other soil properties } \\
\hline Electrical conductivity & -0.19 & -0.13 & - \\
\hline Soil moisture & -0.22 & - & -0.20 \\
\hline Soil bulk density & 0.25 & - & - \\
\hline \multicolumn{4}{|c|}{ Distance } \\
\hline From the trees & 0.18 & - & - \\
\hline From the trails & -0.24 & -0.18 & - \\
\hline
\end{tabular}

The increase in recreational load was associated with changes in the aggregate structure of the soil. As a result of recreation, the proportion of aggregates larger than $7 \mathrm{~mm}$ (macroaggregates) and smaller than $0.5 \mathrm{~mm}$ 
(microaggregates) increased. The decrease in the proportion of mesoaggregates, which are agronomically valuable components of soil structure, leads to negative ecological consequences. Mesoaggregates provide an optimal water and air regime of soil, making optimal conditions for life and development of both root systems of plants and the living of the soil animals (Zhukov et al., 2018; Zadorozhnaya et al., 2018). The soil compaction, which is accompanied by a change in the aggregate structure, leads to a decrease in the living space for soil animals and deterioration of their breathing conditions. The increase in penetration resistance and soil density due to recreational load is consistent with a decrease in soil moisture. Obviously, this trend also negatively affects the abundance of mollusc populations.

Diverse conditions for life of micromolluscs have developed in the gradient of recreational transformation of soil. The most numerous species of micromolluscs was $V$. pulchella, at the same time being the most sensitive to the anthropogenic impact. Under favourable conditions, this species demonstrates the ability to increase its abundance very significantly. However, even a moderate level of recreational impact has a sensitive effect on the abundance of $V$. pulchella. The micromolluscs $C$. lubrica and Acanthinula aculeata had significantly lower population abundances than the $V$. pulchella population. The micromollusc $C$. lubrica responds only to very high levels of recreational pressure. The maximum abundance of A. aculeata populations was observed under moderate recreational pressure.
Table 5

Models of micromollusc response to environmental gradients represented by the principal components, as well as parameters of ecological niches

\begin{tabular}{|c|c|c|c|c|c|c|c|c|c|}
\hline \multirow[t]{2}{*}{ Parameters } & \multicolumn{3}{|c|}{$\begin{array}{c}\mathrm{PC} 1 \\
\text { (diapason of the scores } \\
-4.84-+6.93 \text { ) } \\
\end{array}$} & \multicolumn{3}{|c|}{$\begin{array}{c}\mathrm{PC} 2 \\
\text { (diapason of the scores } \\
-2.63-+4.29 \text { ) } \\
\end{array}$} & \multicolumn{3}{|c|}{$\begin{array}{c}\text { PC3 } \\
\text { (diapason of the scores } \\
-3.43-+2.80 \text { ) } \\
\end{array}$} \\
\hline & VP & $\mathrm{CL}$ & $\mathrm{AA}$ & VP & $\mathrm{CL}$ & $\mathrm{AA}$ & VP & $\mathrm{CL}$ & $\mathrm{AA}$ \\
\hline $\begin{array}{l}\text { Best } \\
\text { model }\end{array}$ & IV & III & IV & IV & I & I & VII & IV & I \\
\hline IQV & 0.85 & 0.83 & 0.59 & 0.83 & 0.71 & 0.40 & 0.53 & 0.88 & 0.89 \\
\hline $\mathrm{Opt}_{\min }$ & -2.37 & -4.84 & -0.77 & 0.94 & - & - & 2.64 & 0.90 & - \\
\hline $\mathrm{Opt}_{\max }$ & - & 1.81 & - & - & - & - & 2.80 & - & - \\
\hline Slope $_{\max }$ & 23.21 & 5.09 & 2.65 & & - & - & 47.11 & 2.55 & - \\
\hline $\mathrm{CB}_{\text {low }}$ & -4.37 & -4.84 & -2.75 & -1.52 & -2.63 & -2.63 & 1.51 & -0.88 & -3.43 \\
\hline $\mathrm{CB}_{\text {high }}$ & -0.37 & 3.03 & 1.21 & 3.39 & 4.29 & 4.29 & 3.77 & 2.66 & 2.80 \\
\hline $\mathrm{OB}_{\text {low }}$ & -6.87 & -4.84 & -5.22 & -2.63 & -2.63 & -2.63 & -1.77 & -3.05 & -3.43 \\
\hline $\mathrm{OB}_{\text {high }}$ & 2.13 & 4.61 & 3.68 & 4.52 & 4.29 & 4.29 & 5.00 & 4.84 & 2.80 \\
\hline
\end{tabular}

Notes: IQV - index of qualitative variation; $\mathrm{Opt}_{\min }$ - optimum minimum edge, $\mathrm{Opt}_{\max }$ optimum maximum edge, Slope $\mathrm{m}_{\max }$ - maximum slope, $\mathrm{CB}_{\text {low }}$ - low edge of the central borders, $\mathrm{CB}_{\text {high }}-$ high edge of the central borders, $\mathrm{OB}_{\text {low }}-$ low edge of the outer borders, $\mathrm{OB}_{\text {high }}-$ high edge of the outer borders; $\mathrm{VP}-V$. pulchella, $\mathrm{CL}-$ C. lubrica, AA - A . aculeata, types of the response models - I - no response, II increasing or decreasing without a plateau, III - increasing or decreasing with a plateau, IV - asymmetric unimodal responses, $\mathrm{V}$ - symmetric unimodal response, VI-bimodal asymmetric, VII - symmetric bimodal response form.
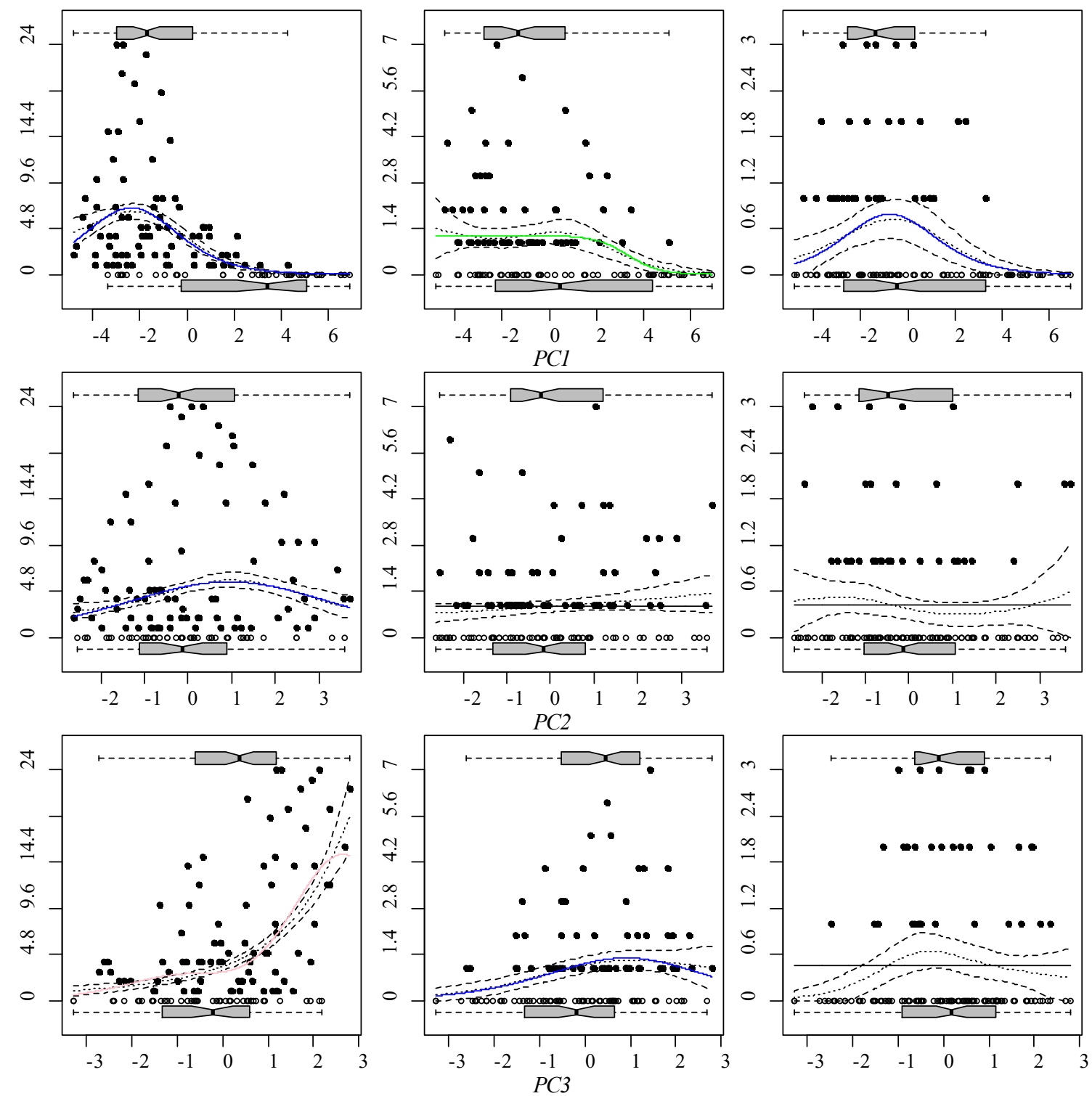

Vallonia pulchella

Cochlicopa lubrica

Acanthinula aculeate

Fig. 2. Models of micromollusc response to environmental gradients represented by the principal components: $\mathrm{x}$-axis - principal component scores, $\mathrm{y}$-axis - species abundance 
All species of micromolluscs show a tendency to a slight decrease in abundance at the opposite pole of the recreational transformation gradient. Increase in mollusc abundance after decrease in recreational load is quite obvious and the reasons for this are clear. In "extremely favourable" conditions, the abundance may decrease for a number of reasons. In favourable conditions, predatory forms of pedobionts may gain an advantage, which can reduce the abundance of micromolluscs. The biotic interactions play an important role in dynamics of mollusc communities due to the fact that land snails are a source of water for many predators, especially in arid conditions (Yom-Tov, 1970; Shachak et al., 2002; Severns, 2007), as well as being a source of energy and nutrients, including calcium (Graveland \& Gijzen, 1994). The total abundance of the micromollusc community reaches a plateau as the level of recreational transformation decreases, indicating that competitive relationships between species are intensifying as the abundance of individual species decreases while the total community abundance remains almost unchanged. The competition among molluscs for trophic resources or moisture can explain the variability in abundance of terrestrial snail populations (Cowie \& Cain, 1983; Pearce, 1997). However, food is not a limiting factor for land snails in many cases (Kimura \& Chiba, 2010), but nonetheless may have an important role (Butler, 1976; Williamson et al., 1976, 1977). Moisture strongly affects snail activity (Martin \& Sommer, 2004), and because snails must move to acquire water resources. A lack of moisture can effectively limit the availability of food, so competition by snails for moist sites is quite possible (Pearce, 1997).

A special zone is formed near the recreational trail, which creates a "halo" around the zone of intense recreational load, which is marked by the principal component 2 . There can be several reasons for the creation of such a zone. Spontaneous recreational trails have a constant direction, but have no constant trajectory, so their location is constantly changing - they "migrate". The traces of impact from the location of the trail in the previous period of time may be the reason for the formation of a corresponding pattern of soil properties. It primarily affects the increase of soil penetration resistance in the deeper soil layers.

The uppermost soil layers may recover their penetration resistance to normal levels earlier, while this process may be delayed in the deeper la- yers. The penetration resistance may be restored to normal levels through the influence of factors of a physical nature and the action of biotic factors. And the relative role of biotic factors increases with depth as a result of the loosening activity of the roots of herbaceous plants. There was practically no herbaceous cover within the studied polygon, so the leading role belongs to the factors of an abiotic nature, the activity of which was the highest in the surface soil layers. This was the impact of precipitation, temperature fluctuations, alternating processes of freezing and melting of water. Also the "halo" near the trails may occur as a result of the formation of a berm along them. Soil compaction in the area of the trail leads to a relative decrease in the soil level. During the rainy season, water accumulates in the trails and the soil is pressed to the borders of the trail. This is how a berm is formed. Moisture rolls off the berm, providing an additional supply of water to adjacent areas. The berm is nothing but "ariduscula" as understood by Vysotsky (a locally elevated, dry, arid area of the soil surface), and the space next to it is "potuscula" as understood by Belgard (a depressed, damper area of the soil surface). We should also note the contrasting conditions of formation of the aggregate structure. The berm was composed of soil with a predominance of macroaggregates, while the soil adjacent to it had a large proportion of microaggregates. The fact that the zone of soil compaction under recreational impact did not have a strictly vertical projection but had a trapezoidal profile with an increasing base can also be seen as a possible mechanism of formation of the "halo". Therefore, the zone of increasing soil hardness in the vicinity of the trail increases with depth. This is fully consistent with the results obtained earlier (Zhukov, 2015). Undoubtedly, we cannot exclude the joint effect of the above causes.

The fact that the principal component 2 reflects features of variation in soil properties predominantly at considerable depth explains the minor importance of this gradient as a factor in changes in the abundance of micromolluscs that inhabit the upper soil layers. The micromollusc $V$. pulchella was observed to have a tendency to locally increase its abundance in the zone adjacent to recreational trails, while the other species were indifferent to this type of impact. It should be clarified that the conclusions obtained are true within the scope of this study. Obviously, the influence of this pattern manifests itself at a fine-scale level, which requires a more detailed sampling grid to reveal.

\section{Table 6}

Response models and range of favourable values of environmental properties presented as central borders (in the case of bimodal models, the most extreme values of estimates are presented; no estimates can be made for Model I)

\begin{tabular}{|c|c|c|c|c|c|c|}
\hline \multirow{2}{*}{ Variables } & \multicolumn{2}{|c|}{ Vallonia pulchella } & \multicolumn{2}{|c|}{ Cochlicopa lubrica } & \multicolumn{2}{|c|}{ Acanthinula aculeata } \\
\hline & model & diapason & model & diapason & model & diapason \\
\hline \multicolumn{7}{|c|}{ Soil penetration resistance at a depth of, $\mathrm{cm}$ in $\mathrm{MPa}$} \\
\hline $0-5$ & VII & $1.43-5.97$ & I & - & III & $1.10-3.94$ \\
\hline $5-10$ & VI & $3.06-8.00$ & III & $2.60-6.25$ & III & $2.60-5.75$ \\
\hline $10-15$ & VII & $4.00-9.89$ & III & $3.40-7.68$ & IV & $4.05-6.84$ \\
\hline $15-20$ & IV & $4.49-7.22$ & $\mathrm{I}$ & - & IV & $5.22-7.76$ \\
\hline $20-25$ & $\mathrm{~V}$ & $5.43-7.85$ & II & $4.60-7.00$ & II & $4.60-6.76$ \\
\hline $25-30$ & VII & $5.94-10.33$ & IV & $5.96-8.68$ & I & - \\
\hline $30-35$ & VII & $5.67-8.80$ & II & $5.80-7.73$ & I & - \\
\hline $35-40$ & VII & $5.99-9.08$ & III & $6.00-9.34$ & I & - \\
\hline $40-45$ & VII & $4.19-10.86$ & I & - & IV & $7.54-9.55$ \\
\hline $45-50$ & VII & $4.82-9.06$ & $\mathrm{I}$ & - & I & - \\
\hline \multicolumn{7}{|c|}{ Aggregate fraction, in $\%$} \\
\hline$>10 \mathrm{~mm}$ & II & $2.60-6.51$ & II & $2.60-8.97$ & I & - \\
\hline $7-10 \mathrm{~mm}$ & VII & $5.40-12.87$ & I & - & $\mathrm{I}$ & - \\
\hline $5-7 \mathrm{~mm}$ & III & $7.81-11.10$ & III & $7.01-11.10$ & IV & $7.53-10.27$ \\
\hline $3-5 \mathrm{~mm}$ & II & $12.77-14.40$ & II & $11.67-14.40$ & III & $8.68-14.40$ \\
\hline $2-3 \mathrm{~mm}$ & II & $12.13-14.30$ & III & $7.97-14.30$ & III & $8.50-14.30$ \\
\hline $1-2 \mathrm{~mm}$ & VII & $11.71-21.46$ & IV & $11.83-19.36$ & I & - \\
\hline $0.5-1 \mathrm{~mm}$ & III & $2.40-3.40$ & II & $2.60-3.40$ & I & - \\
\hline $0.25-0.5 \mathrm{~mm}$ & $\mathrm{~V}$ & $9.19-14.69$ & I & - & I & - \\
\hline$<0.25 \mathrm{~mm}$ & VII & $14.53-30.58$ & II & $15.40-24.59$ & I & - \\
\hline \multicolumn{7}{|c|}{ Other soil properties } \\
\hline Electrical conductivity, $\mathrm{dSm} / \mathrm{m}$ & $\mathrm{V}$ & $0.06-0.08$ & I & - & IV & $0.06-0.08$ \\
\hline Soil moisture, $\%$ & VII & $5.82-10.60$ & I & - & I & - \\
\hline Soil bulk density, $\mathrm{g} / \mathrm{cm}^{3}$ & II & $0.96-1.03$ & II & $0.96-1.12$ & II & $0.96-1.07$ \\
\hline \multicolumn{7}{|c|}{ Distance, $m$} \\
\hline From the trees & VII & $0.00-3.39$ & II & $0.32-2.90$ & II & $0.32-2.05$ \\
\hline From the route trails & $\mathrm{V}$ & $1.95-5.94$ & IV & $1.26-7.11$ & III & $1.06-10.18$ \\
\hline
\end{tabular}

Notes: types of the response models - I - no response, II - increasing or decreasing without a plateau, III - increasing or decreasing with a plateau, IV - asymmetric unimodal responses, V- symmetric unimodal response, VI- bimodal asymmetric, VII - symmetric bimodal response form. 
The natural variability of soil properties is due to reasons that do not depend on the distance from the recreational trails. Therefore, the variability of soil properties, which is indicated by principal component 3 , was estimated as natural variability. It should be noted that the patterns described by the principal component 1 may have originally had natural causes for their occurrence. Such causes correlate with distance from trees. The location of spontaneous trails is determined so that they are conventionally equidistant from the nearest trees. Therefore, the variability induced by recreation is superimposed on the natural variability of the soil properties, which is induced by distance from the trees. The principal component 3 indicates the important role of mesoaggregates for the formation of optimal living conditions for micromolluscs. It is this size fraction of aggregates that provide the best conditions for favourable water and air regime, which positively influences both micromolluscs themselves and their trophic objects.

\section{Conclusion}

The recreational impact in the form of spontaneous trails significantly alters the soil properties in artificial park plantations. The zone of influence of such transformation significantly exceeds the visible boundaries of the trails. The main trends of transformation are increase in soil penetration resistance and soil density, deterioration of air and water regime, alteration of soil aggregate structure. Such transformation affects the living conditions of soil micromolluscs. Their abundance and diversity is significantly high in undisturbed conditions. Near the trails, living conditions deteriorate, leading to a sharp decrease in micromollusc abundance. Vallonia pulchella is the most sensitive to recreational pressure. The micromolluscs C. lubrica and A. aculeata are more resistant to recreational pressure, but their abundance is lower than such of $V$. pulchella. Competition between species is important in micromollusc community dynamics under low anthropogenic pressure. Abiotic factors increased in importance with increasing recreational transformation of soil.

\section{References}

Al-Shammary, A. A. G., Kouzani, A. Z., Kaynak, A., Khoo, S. Y., Norton, M., \& Gates, W. (2018). Soil bulk density estimation methods: A review. Pedosphere, 28(4), 581-596.

Asabere, S. B., Zeppenfeld, T., Nketia, K. A., \& Sauer, D. (2018). Urbanization leads to increases in $\mathrm{pH}$, carbonate, and soil organic matter stocks of arable soils of kumasi, Ghana (West Africa). Frontiers in Environmental Science, 6, 119.

Azlin, Y. N., \& Philip, E. (2004). Soil compaction and tree decline along a recreational forest trail in Malaysia. Arboricultural Joumal, 27(3), 239-243.

Balashov, I. A., Neiber, M. T., \& Hausdorf, B. (2020). Phylogeny, species delimitation and population structure of the steppe-inhabiting land snail genus Helicopsis in Eastern Europe. Zoological Journal of the Linnean Society, 2020, zlaa156.

Ballantyne, M., \& Pickering, C. M. (2015). The impacts of trail infrastructure on vegetation and soils: Current literature and future directions. Journal of Environmental Management, 164, 53-64.

Baur, A., \& Baur, B. (1988). Individual movement patterns of the minute land snail Punctum pygmaeum (Draparnaud) (Pulmonata: Endodontidae). Veliger, 30, 372-376.

Bird, S. B., Herrick, J. E., Wander, M. M., \& Murray, L. (2007). Multi-scale variability in soil aggregate stability: Implications for understanding and predicting semi-arid grassland degradation. Geoderma, 140, 106-118.

Boycott, A. E. (1934). The habitats of land mollusca in Britain. The Journal of Ecology, 22(1), 1-38.

Brygadyrenko, V. V. (2014). Influence of soil moisture on litter invertebrate community structure of pine forests of the steppe zone of Ukraine. Folia Oecologica, 41(1), 8-16.

Brygadyrenko, V. V. (2015). Influence of tree crown density and density of the herbaceous layer on the structure of litter macrofauna of deciduous forests of Ukraine's steppe zone. Visnyk of Dnipropetrovsk University, Biology, Ecology, 23(2), 134-148.

Brygadyrenko, V. V. (2016a). Effect of canopy density on litter invertebrate community structure in pine forests. Ekológia (Bratislava), 35(1), 90-102.

Brygadyrenko, V. V. (2016b). Influence of litter thickness on the structure of litter macrofauna of deciduous forests of Ukraine's steppe zone. Visnyk of Dnipropetrovsk University, Biology, Ecology, 24(1), 240-248.

Burnham, K. P., \& Anderson, D. R. (2002). Model selection and multi-model inference: A practical information - theoretic approach. Springer, Berlin.

Butler, A. J. (1976). A shortage of food for the terrestrial snail Helicella virgata in South Australia. Oecologia, 25(4), 349-371.
Campbell, D. M. H., White, B., \& Arp, P. A. (2013). Modeling and mapping soil resistance to penetration and rutting using LiDAR-derived digital elevation data. Joumal of Soil and Water Conservation, 68(6), 460-473.

Čejka, T., \& Hamerlík, L. (2009). Land snails as indicators of soil humidity in Danubian woodland (SW Slovakia). Polish Journal of Ecology, 57(4), 741-747.

Cejka, T., Horsak, M., \& Nemethova, D. (2007). The composition and richness of Danubian floodplain forest land snail faunas in relation to forest type and flood frequency. Joumal of Molluscan Studies, 74(1), 37-45.

Cernohorsky, N. H., Horsák, M., \& Cameron, R. A. D. (2010). Land snail species richness and abundance at small scales: The effect of distinguishing between live individuals and empty shells. Journal of Conchology, 40, 233-241.

Chiba, S. (2007). Species richness patterns along environmental gradients in island land molluscan fauna. Ecology, 88(7), 1738-1746.

Cowie, R. H. (2009). Microhabitat choice and high temperature tolerance in the land snail Theba pisana (Mollusca: Gastropoda). Journal of Zoology, 207(2), 201-211.

Cowie, R. H., \& Cain, A. J. (1983). Laboratory maintenance and breeding of land snails, with an example from Helix aspersa. Joumal of Molluscan Studies, 49(2), 176-177.

Davies, P., Gale, C. H., \& Lees, M. (1996). Quantitative studies of modern wetground molluscan faunas from Bossington, Hampshire. Journal of Biogeography, 23(3), 371-377.

de Fraga, R., Ferrão, M., Stow, A. J., Magnusson, W. E., \& Lima, A. P. (2018). Different environmental gradients affect different measures of snake $\beta$-diversity in the Amazon rainforests. PeerJ, 6, e5628.

Didukh, Y. P. (2011). The ecological scales for the species of Ukrainian flora and their use in synphytoindication. Phytosociocentre, Kyiv.

Douglas, D. D., Brown, D. R., \& Pederson, N. (2013). Land snail diversity can reflect degrees of anthropogenic disturbance. Ecosphere, 4(2), art28.

El-Gendy, K. S., Gad, A. F., \& Radwan, M. A. (2021). Physiological and behavioral responses of land molluscs as biomarkers for pollution impact assessment: A review. Environmental Research, 193, 110558.

Ellenberg, H., Weber, H. E., Dull, R., Wirth, V., Werner, W., \& Paulissen, D. (1992). Zeigerwerte von Pflanzen in Mitteleuropa. Scripta Geobotanica, 104, 284-285.

Evans, J. G. (1972). Land snails in archaeology. Seminar Press, London, New York.

Fattet, M., Fu, Y., Ghestem, M., Ma, W., Foulonneau, M., Nespoulous, J., Le Bissonnais, Y., \& Stokes, A. (2011). Effects of vegetation type on soil resistance to erosion: Relationship between aggregate stability and shear strength. Catena, 87(1), 60-69.

Gołas-Siarzewska, M. (2013). Malacofauna of the Wawel Hill in Cracow (Poland) a quarter of a century after its first description. Folia Malacologica, 21(1), 19-23.

Goncharenko, I. V., \& Yatsenko, H. M. (2020). Phytosociological study of the forest vegetation of Kyiv urban area (Ukraine). Hacquetia, 19(1), 99-126.

Graham, L. J., \& Eigenbrod, F. (2019). Scale dependency in drivers of outdoor recreation in England. People and Nature, 1(3), 406-416.

Graveland, J., \& Gijzen, T. (1994). Arthropods and seeds are not sufficient as calcium sources for shell formation and skeletal growth in passerines. Ardea, 82, 299-314.

Groffman, P. M., Cavender-Bares, J., Bettez, N. D., Grove, J. M., Hall, S. J., Heffernan, J. B., Hobbie, S. E., Larson, K. L., Morse, J. L., Neill, C., Nelson, K., O’Neil-Dunne, J., Ogden, L., Pataki, D. E., Polsky, C., Chowdhury, R. R., \& Steele, M. K. (2014). Ecological homogenization of urban USA. Frontiers in Ecology and the Environment, 12(1), 74-81.

Heegaard, E. (2002). The outer border and central border for species - Environmental relationships estimated by non-parametric generalised additive models. Ecological Modelling, 157, 131-139.

Hettenbergerová, E., Horsák, M., Chandran, R., Hájek, M., Zelený, D., \& Dvoř́ková, J. (2013). Patterns of land snail assemblages along a fine-scale moisture gradient. Malacologia, 56, 31-42.

Hill, M. O., Roy, D. B., \& Thompson, K. (2002). Hemeroby, urbanity and ruderality: Bioindicators of disturbance and human impact. Journal of Applied Ecology, 39(5), 708-720.

Horáčková, J., Horsák, M., \& Juřčková, L. (2014). Land snail diversity and composition in relation to ecological variations in Central European floodplain forests and their history. Community Ecology, 15(1), 44-53.

Horn, J. L. (1965). A rationale and test for the number of factors in factor analysis. Psychometrika, 30(2), 179-185.

Horsák, M. (2006). Mollusc community patterns and species response curves along a mineral richness gradient: A case study in fens. Journal of Biogeography, 33(1), 98-107.

Horsák, M., \& Cernohorsky, N. (2008). Mollusc diversity patterns in Central European fens: Hotspots and conservation priorities. Joumal of Biogeography, 35(7), 1215-1225.

Horsák, M., \& Hájek, M. (2003). Composition and species richness of molluscan communities in relation to vegetation and water chemistry in the Western Carpathian spring fens: The poor-rich gradient. Journal of Molluscan Studies, 69(4), 349-357. 
Horsák, M., Hájek, M., Dítě, D., \& Tichý, L. (2007). Modern distribution patterns of snails and plants in the Western Carpathian spring fens: Is it a result of historical development? Joumal of Molluscan Studies, 73(1), 53-60.

Horsák, M., Juřičková, L., Kintrová, K., \& Hájek, O. (2009). Patterns of land snail diversity over a gradient of habitat degradation: A comparison of three Czech cities. Biodiversity and Conservation, 18(13), 3453-3466.

Horsák, M., Lososová, Z., Čejka, T., Jư̌ičková, L., \& Chytrý, M. (2013). Diversity and biotic homogenization of urban land-snail faunas in relation to habitat types and macroclimate in 32 central european cities. PLoS One, 8(8), e71783.

Huang, X., Sheng, Z., Zhang, Y., Ding, J., \& He, K. (2015). Impacts of trails on plants, soil and their interactions in the subalpine meadows of Mount Jade Dragon, Northwestern Yunnan of China. Grassland Science, 61(4), 204-216.

Huisman, J., Olff, H., \& Fresco, L. F. M. (1993). A hierarchical set of models for species response analysis. Journal of Vegetation Science, 4(1), 37-46.

Hylander, K., Nilsson, C., Gunnar Jonsson, B., \& Göthner, T. (2005). Differences in habitat quality explain nestedness in a land snail meta-community. Oikos, 108(2), 351-361.

Ihtimanski, I., Nedkov, S., \& Semerdzhieva, L. (2020). Mapping the natural heritage as a source of recreation services at national scale in Bulgaria. One Ecosystem, $5, \mathrm{e} 54621$

Jankowiak, A., \& Bernard, R. (2013). Coexistence or spatial segregation of some Vertigo species (Gastropoda: Vertiginidae) in a Carex rich fen in Central Poland? Journal of Conchology, 41, 399-406.

Jansen, F., \& Oksanen, J. (2013). How to model species responses along ecological gradients - Huisman-Olff-Fresco models revisited. Journal of Vegetation Science, 24(6), 1108-1117.

Jorat, M. E., Goddard, M. A., Manning, P., Lau, H. K., Ngeow, S., Sohi, S. P., \& Manning, D. A. C. (2020). Passive $\mathrm{CO}_{2}$ removal in urban soils: Evidence from brownfield sites. Science of the Total Environment, 703, 135573.

Juřičková, L., Horsák, M., Cameron, R., Hylander, K., Míkovcová, A., Hlaváč, J. Č., \& Rohovec, J. (2008). Land snail distribution patterns within a site: The role of different calcium sources. European Journal of Soil Biology, 44(2), 172-179.

Kaiser, H. F. (1970). A second generation little jiffy. Psychometrika, 35(4), 401-415.

Kaiser, H. F. (1974). An index of factorial simplicity. Psychometrika, 39(1), 31-36.

Kaiser, H. F., \& Rice, J. (1974). Little Jiffy, Mark IV. Educational and Psychological Measurement, 34(1), 111-117.

Karlin, E. J. (1961). Ecological relationships between vegetation and the distribution of land snails in Montana, Colorado and New Mexico. American Midland Naturalist, 65(1), 60

Kimura, K., \& Chiba, S. (2010). Interspecific interference competition alters habitat use patterns in two species of land snails. Evolutionary Ecology, 24(4), 815-825.

Korchagina, K. V., Smagin, A. V., \& Reshetina, T. V. (2014). Assessing the technogenic contamination of urban soils from the profile distribution of heavy metals and the soil bulk density. Eurasian Soil Science, 47(8), 824-833.

Kroetsch, D., \& Wang, C. (2008). Particle size distibution. In: Carter, M. R. \& Gregorich, E. G. (Eds.). Soil sampling and methods of analysis. CRC Press, Boca Raton. Pp. 713-726.

Książkiewicz, Z., \& Gołdyn, B. (2015). Needle in a haystack: Predicting the occurrence of wetland invertebrates on the basis of simple geographical data. A case study on two threatened micro-mollusc species (Gastropoda: Vertiginidae) from Poland. Wetlands, 35(4), 667-675.

Książkiewicz, Z., Kiaszewicz, K., \& Gotdyn, B. (2013). Microhabitat requirements of five rare vertiginid species (Gastropoda, Pulmonata: Vertiginidae) in wetlands of Western Poland. Malacologia, 56, 95-106.

Książkiewicz-Parulska, Z., \& Ablett, J. D. (2017). Microspatial distribution of molluscs and response of species to litter moisture, water levels and eutrophication in moist, alkaline ecosystems. Belgian Journal of Zoology, 147(1), 37-53.

Książkiewicz-Parulska, Z., \& Pawlak, K. (2016). Rare species of micromolluscs in the city of Poznan (W. Poland) with some notes on wintering of Vertigo moulinsiana (Dupuy, 1849). Folia Malacologica, 24(2), 97-101.

Kuczyńska, A., \& Moorkens, E. (2010). Micro-hydrological and micro-meteorological controls on survival and population growth of the whorl snail Vertigo geyeri Lindholm, 1925 in groundwater fed wetlands. Biological Conservation, 143(8), 1868-1875.

Kunakh, O. N., Kramarenko, S. S., Zhukov, A. V., Kramarenko, A. S., \& Yorkina, N. V. (2018). Fitting competing models and evaluation of model parameters of the abundance distribution of the land snail Vallonia pulchella (Pulmonata, Valloniidae). Regulatory Mechanisms in Biosystems, 9(2), 198-202.

Kunakh, O. N., Kramarenko, S. S., Zhukov, A. V., Zadorozhnaya, G. A., \& Kramarenko, A. S. (2018). Intra-population spatial structure of the land snail Vallonia pulchella (Müller, 1774) (Gastropoda; Pulmonata; Valloniidae). Ruthenica, 28(3), 91-99.

Landsberg, J. D., Miller, R. E., Anderson, H. W., \& Tepp, J. S. (2003). Bulk density and soil resistance to penetration as affected by commercial thinning in Northeastem Washington. Portland.

Lososová, Z., Horsák, M., Chytrý, M., Čejka, T., Danihelka, J., Fajmon, K., Hájek, O., Juřčková, L., Kintrová, K., Láníková, D., Otýpková, Z., Rehořek, V., \& Tichý, L. (2011). Diversity of Central European urban biota: Effects of human- made habitat types on plants and land snails. Joumal of Biogeography, 38(6), $1152-1163$.

Lovett, G. M., Traynor, M. M., Pouyat, R. V., Carreiro, M. M., Zhu, W. X., \& Baxter, J. W. (2000). Atmospheric deposition to oak forests along an urban - rural gradient. Environmental Science and Technology, 34(20), 42944300.

Machin, J. (2009). Structural adaptation for reducing water-loss in three species of terrestrial snail. Journal of Zoology, 152(1), 55-65.

Maier, M. J. (2015). Companion Package to the Book "R: Einfuhrung durch angewandte Statistik". R package version 0.9.3.

Martin, K., \& Sommer, M. (2004). Relationships between land snail assemblage patterns and soil properties in temperate-humid forest ecosystems. Joumal of Biogeography, 31(4), 531-545.

Michaelis, J., \& Diekmann, M. R. (2017). Biased niches - species response curves and niche attributes from Huisman-Olff-Fresco models change with differing species prevalence and frequency. PLoS One, 12(8), 1-16.

Moreno-Rueda, G. (2014). Distribution of arid-dwelling land snails according to dryness. Joumal of Arid Environments, 103, 80-84

Mueller, J. H., \& Schuessler, K. F. (1962). Statistical reasoning in sociology. Houghton Mifflin Company, Boston.

Myšák, J., Horsák, M., Svobodová, E., \& Cernohorsky, N. (2013). Small-scale distribution of terrestrial snails: Patterns of species richness and abundance related to area. Journal of Molluscan Studies, 79(2), 118-127.

Nekola, J. C., \& Smith, T. M. (1999). Terrestrial gastropod richness patterns in Wisconsin carbonate cliff communities. Malacologia, 41(1), 253-269.

Nunes, G., \& Santos, S. (2012). Environmental factors affecting the distribution of land snails in the Atlantic Rain Forest of Ilha Grande, Angra dos Reis, RJ, Brazil. Brazilian Journal of Biology, 72(1), 79-86

Pearce, T. A. (1997). Interference and resource competition in two land snails: Adults inhibit conspecific juvenile growth in field and laboratory. Journal of Molluscan Studies, 63(3), 389-399.

Pouyat, R. V., Yesilonis, I. D., Szlavecz, K., Csuzdi, C., Hornung, E., Korsós, Z Russell-Anelli, J., \& Giorgio, V. (2008). Response of forest soil properties to urbanization gradients in three metropolitan areas. Landscape Ecology, 23(10), 1187-1203.

Putchkov, A. V., Brygadyrenko, V. V., \& Markina, T. Y. (2019). Ground beetles of the tribe Carabini (Coleoptera, Carabidae) in the main megapolises of Ukraine. Vestnik Zoologii, 53(1), 3-12.

R Core Team. (2020). R: A language and environment for statistical computing (3.6.3). R Foundation for Statistical Computing, Vienna, Austria

Renforth, P., Manning, D. A. C., \& Lopez-Capel, E. (2009). Carbonate precipitation in artificial soils as a sink for atmospheric carbon dioxide. Applied Geochemistry, 24(9), 1757-1764.

Rydgren, K., Økland, R. H., \& Økland, T. (2003). Species response curves along environmental gradients. A case study from SE Norwegian swamp forests. Journal of Vegetation Science, 14(6), 869-880

Santos, X., Bros, V., \& Ros, E. (2012). Contrasting responses of two xerophilous land snails to fire and natural reforestation. Contributions to Zoology, 81(3), $167-180$.

Scheffers, B. R., Edwards, D. P., Diesmos, A., Williams, S. E., \& Evans, T. A (2014). Microhabitats reduce animal's exposure to climate extremes. Global Change Biology, 20(2), 495-503.

Schenková, V., Horsák, M., Hájek, M., Plesková, Z., Dítě, D., \& Pawlikowski, P. (2014). Mollusc and plant assemblages controlled by different ecological gradients at Eastern European fens. Acta Oecologica, 56, 66-73.

Seifritz, W. (1990). $\mathrm{CO}_{2}$ disposal by means of silicates. Nature, 345(6275), 486-486.

Severns, P. M. (2007). Does standing water and predator presence structure a wetland terrestrial mollusc community? Wetlands, 27(4), 964-971.

Shachak, M., Leeper, A., \& Degen, A. (2002). Effect of population density on water influx and distribution in the desert snail Trochoidea seetzenii. Écoscience, 9(3) 287-292.

Shelford, V. E. (1911). Ecological succession. I. Stream fishes and the method of physiographic analysis. The Biological Bulletin, 21(1), 9-35.

Shelford, V.E. (1931). Some concepts of bioecology. Ecology, 12(3), 455- 467.

Smagin, A. V., Azovtseva, N. A., Smagina, M. V., Stepanov, A. L., Myagkova A. D., \& Kurbatova, A. S. (2006). Criteria and methods to assess the ecological status of soils in relation to the landscaping of urban territories. Eurasian Soil Science, 39(5), 539-551.

Stoll, P., Gatzsch, K., Rusterhol, H.-P., \& Baur, B. (2012). Response of plant and gastropod species to knotweed invasion. Basic and Applied Ecology, 13(3), 232-240.

Ström, L., Hylander, K., \& Dynesius, M. (2009). Different long-term and short-term responses of land snails to clear-cutting of boreal stream-side forests. Biological Conservation, 142(8), 1580-1587.

Sulikowska-Drozd, A., \& Horsák, M. (2007). Woodland mollusc communities along environmental gradients in the East Carpathians. Biologia, 62(2), 201-209.

Szybiak, K., Błoszyk, J., Koralewska-Batura, E., \& Gołdyn, B. (2009). Small-scale distribution of wintering terrestrial snails in forest site: Relation to habitat conditions. Polish Joumal of Ecology, 57(3), 525-535. 
Tomczyk, A. M., \& Ewertowski, M. W. (2016). Recreational trails in the Poprad Landscape Park, Poland: The spatial pattern of trail impacts and use-related, environmental, and managerial factors. Journal of Maps, 12(5), 1227-1235.

Vasenev, V. I., Smagin, A. V., Ananyeva, N. D., Ivashchenko, K. V., Gavrilenko, E. G., Prokofeva, T. V., Patlseva, A., Stoorvogel, J. J., Gosse, D. D., \& Valentini, R. (2017). Urban soil's functions: Monitoring, assessment, and management. In: Adaptive soil management: From theory to practices. Springer Singapore, Singapore. Pp. 359-409.

Wäreborn, I. (1969). Land molluscs and their environments in an oligotrophic area in Southem Sweden. Oikos, 20, 461-479.

Williamson, P., Cameron, R. A. D., \& Carter, M. A. (1976). Population density affecting adult shell size of snail Cepaea nemoralis L. Nature, 263(5577), 496-497.

Williamson, P., Cameron, R. A. D., \& Carter, M. A. (1977). Population dynamics of the landsnail Cepaea nemoralis L.: A six-year study. The Joumal of Animal Ecology, 46(1), 181-194.

Yom-Tov, Y. (1970). The effect of predation on population densities of some desert snails. Ecology, 51(5), 907-911.

Yorkina, N. V. (2016). Impact of technogenic pollution of urban environment on vitality indicators of urban biota (mollusk fauna, soil mesofauna, epiphytic lichens). Moscow University Biological Sciences Bulletin, 71(3), 177-183.

Yorkina, N., Maslikova, K., Kunah, O., \& Zhukov, O. (2018). Analysis of the spatial organization of Vallonia pulchella (Muller, 1774) ecological niche in technosols (Nikopol Manganese Ore Basin, Ukraine). Ecologica Montenegrina, 17, $29-45$.

Yorkina, N., Zhukov, O., \& Chromysheva, O. (2019). Potential possibilities of soil mesofauna usage for biodiagnostics of soil contamination by heavy metals. Ekologia Bratislava, 38(1), 1-10.
Yurkova, N. E., Yurkov, A. M., \& Smagin, A. V. (2009). Ecological status of soils in Moscow Zoo. Eurasian Soil Science, 42(3), 342-348.

Zadorozhnaya, G. A., Andrusevych, K. V., \& Zhukov, O. V. (2018). Soil heterogeneity after recultivation: Ecological aspect. Folia Oecologica, 45(1), 46-52.

Zarzycki, K., Trzcinska-Tacik, H., Rozanski, W., Szelag, Z., Wolek, J., \& Korzeniak, U. (2002). Ecological indicator values of vascular plants of Poland [Ekologiczne liczby wskaznikowe roślin naczyniowych Polski]. Instytut Botaniki im. W. Szafera, Polska Akademia Nauk, Kraków.

Zhukov, A. V. (2015). Influence of usual and dual wheels on soil penetration resistance: the GIS-approach. Biological Bulletin of Bogdan Chmelnitskiy Melitopol State Pedagogical University, 5(3), 73-100.

Zhukov, O. V., Kunah, O. M., Dubinina, Y. Y., Fedushko, M. P., Kotsun, V. I., Zhukova, Y. O., \& Potapenko, O. V. (2019). Tree canopy affects soil macrofauna spatial patterns on broad- and meso-scale levels in an Eastern European poplarwillow forest in the floodplain of the River Dnipro. Folia Oecologica, 46(2), $101-114$.

Zhukov, O. V., Kunakh, O. M., Taran, V. O., \& Lebedinska, M. M. (2016). Spatial variability of soils electrical conductivity within arena of the river Dnepr valley (territory of the natural reserve "Dniprovsko-Orilsky"). Biological Bulletin of Bogdan Chmelnitskiy Melitopol State Pedagogical University, 6(2), 129-157.

Zhukov, O., Kunah, O., Dubinina, Y., \& Novikova, V. (2018). The role of edaphic, vegetational and spatial factors in structuring soil animal communities in a floodplain forest of the Dnipro river. Folia Oecologica, 45, 8-23. 